\title{
ESPONTANEIDAD Y SENCILLEZ DE LA IDEOLOGIA DE LO JUSTO
}

\author{
Manuel María Zorrilla Ruiz
}

Sumario: 1. Fisonomía y ALCANCE DEL Derecho CONSTITUIDO. 2. Mudanzas Reductoras de las ideologías. 3. SERVIDUMBre Y GRANDEZA DE LOS CAMBIOS IDEOLÓGICOS. 4. REACCIÓN DE LOS ORDENAMIENTOS JURÍDICOS FRENTE A LOS CAMBIOS SOCIALES Y POLÍTICOS QUE HAN DE SOPORTAR. 5. ¿CÓMO ACAECE Y TOMA POSICIONES LA ROTACIÓN POLÍtiCA DE LAS IDEOLOGÍAs? 6. ACCESO A LA IDEOLOGÍA DE LO JUSTO. 7. HACIA UNA RECOMPOSICIÓN SALUDABLE Y UN ADECUADO ENTENDIMIENTO DE LO JUSTO. 8. POSIBILIDADES Y PERSPECTIVAS DEL ACERCAMIENTO A UNA IDEOLOGÍA DE LO JUSTO. 9. BIBLIOGRAFÍA.

\section{FISONOMÍA Y ALCANCE DEL DERECHO CONSTITUIDO}

Las reflexiones hechas a continuación intentan reconocer y definir, desde la más amplia perspectiva, uno de los rasgos cuyo significado ayuda a comprender las parcelas del ordenamiento jurídico que -tras advertir, por imperativo constitucional o en virtud del decisionismo político, los intereses generales expuestos a su amparo- se los apropia y regula conforme a la recta razón. Un dictamen que apunta soluciones aptas para elevarlos -previo estudio de sus deficiencias y vestidura de sus desnudeces- a la categoría de derechos subjetivos o situaciones jurídicas. Son éstos susceptibles de actuaciones pacíficas avaladas por el resto de la comunidad en cuyo círculo se inscriben o -si se ha entablado controversia sobre las mismas- vigorizadas por las acciones procesales que se deducen a la manera del derecho en pie de guerra. Aspiran -tras un proceso gobernado por el principio de igualdad material de las partes que en él intervienen-a obtener una respuesta judicial -sustantiva, convincente y libre de injustificadas dilaciones- a la denuncia de su vulneración. Esa nota diferenciadora, junto a otras que cuentan con una dosis plausible de razonabilidad, disipa las eventuales nebulosas y permite asumir un 
modelo común a los sectores que -poblando un universo exento de lagunasratifican la plenitud del ordenamiento jurídico. Tales operaciones requieren una reflexión -pausada y sensible- que presupone la certidumbre o, al menos, la sensatez metodológica de los criterios que -orientados en dicha dirección- se estiman adecuados para llevar al mejor de los fines los proyectos cuya perfección denota el mérito de haberlos descubierto sin mayor esfuerzo o a través de una abrumadora indagación. De ahí, lo meritorio del empeño que impulsa ese trabajo e impide soslayar sus irrenunciables objetivos.

Nadie ignora -sobre todo quienes tozudamente sostienen lo contrarioque, en la interioridad de un sector del ordenamiento jurídico, resuenan, como indicación premonitoria, los ecos de las propensiones ideológicas que traslucen la voluntad decisionista emanada de los legisladores ordinarios mediante arbitrios racionales que, tras ingresar en el patrimonio políticolegislativo, acrecientan y, en su caso, mejoran el Derecho Positivo vigente. Las sugerencias normativas de aspecto más neutral o las apuestas intelectualistas -que, con suerte variable, frenan la precipitación voluntarista- protegen unos reductos ideológicos que, pese al denuedo invertido en la tarea de minimizarlos o aliviar su peso específico, no desdibujan el pluralismo ni el color de los pensamientos y acciones que se infieren de su fisonomía. Muchas formulaciones normativas -comprensivas de los mismos tipos rectores y sugerentes de consecuencias jurídicas iguales- se asemejen a los libretos de una composición musical cuyo texto inmutable tolera partituras melódicamente inconciliables o emocionalmente divididas. Cada ideología es tributaria de un mínimo de inspiración política que asimila las claves de una identidad dudosa o irreconocible de otro modo.

La lucha por el Derecho propugnó la figura o el sumo deseable de dos categorías de actos. Una incluía las depuraciones que cribaban los materiales híbridos, ponderaban la heterogéneidad de los accesibles al conocimiento intelectual y expulsaban las sobrecargas empobrecedoras. Otra implicaba la mejora que demostrase la excelencia de la depuración, avalando la calidad de los modelos que los procesos de universalidad y tecnificación jurídica importaban para tratar sensiblemente los valores que, en busca de su arraigo, incitaban a conquistar las cumbres donde iban a izarse sus banderas. La instalación irreversible del Derecho, que asegura la vida social en dignidad y reconforta su supervivencia, le convierte -sin merma de los designios pacificadores que, por hipótesis, le incumben- en un instrumento contundente de transformación. Además de su aportación originaria, se incorporan las sugerencias ideológicas que acercan al depósito de las verdades de una filosofía jurídica -más retadoras y enjundiosas que las de una ciencia del Derecho- cuya condición de disciplina científica se objeta con razones de escasa consistencia. Fomenta sus procesos de cambio, inaplazables, los unos, o graduales, los otros, sin que los de más lenta evolución se desliguen de sus reivindicaciones inmediatas. No en vano, las corrientes conexas con los aspectos amablemente pedagógi- 
cos e incluso edificantes del pensamiento marxista -entre ellos, el augurio optimista con que la cláusula transformadora y social del art. 3 II CI (Constitución italiana de 27 de diciembre de 1947) predijo, sin el triunfo esperado de su emotivo compromiso, su traslación al escenario jurídicopolítico de la cultura occidental- otorgaron al papel pacificador o disolvente de conflictos una postura compartida. Aceptando ser ésta una de las funciones naturales del Derecho constituido y apelando a la tesis de la revolución incruenta o venida de lo alto, recordaron la urgencia de que los adelantos de la sociedad estratificada y pluralista de la época ganasen en protagonismo y potencial transformador. Opciones de recreación y crecimiento, primero latentes y después vertidas en proyectos inéditos, seductores para los ciudadanos y los grupos intermedios que, erigidos en comunidades, provenían de colectividades cuyos cuerpos y almas se entretejían en el curso de esta evolución.

La ordenación sistemática -tan fatigosa como expuesta a las tosquedades de diagnóstico- de las ideologías clasificables, no de las menudencias del pensamiento deslavazado o desnutrido, se realiza aplicando a las soluciones del Derecho objetivo un coeficiente implícito que permite conocer el grosor de los compromisos contraídos por las normas jurídicas de traza inofensiva o aséptica. El art. 3.1 C.c. (Código Civil español de 26 de julio de 1889, reformado por la Ley de 31 de mayo de 1974) supera la teoría del uso alternativo del Derecho y recupera el concepto de espiritu móvil que la curiosidad interpretativa de los canonistas medioevales asociaba a las aplicaciones del Derecho objetivo de su tiempo. A imagen y semejanza suya, los criterios inspiradores -cuales el espíritu y la finalidad con que se refrenda la penetraciòn de una voluntad sobrevenida- reducen a sus términos justos y actualizan la $p a-$ ternidad originalista de los legisladores que emitieron sus mandatos y prohibiciones. Esta sustitución responde al incremento y las mudanzas de las realidades sociales, distinguidas, al menos, por su emergencia diferenciadora en los espacios autonómicos que delimitan los arts. 2, 143.1 y 144 a) y b) CE. (Constitución española de 27 de diciembre de 1978). Los cambios de cada realidad social -indubitada y perceptible- dimanan de su impacto en los procesos de asimilación del Derecho objetivo, le adaptan a la sanidad de las circunstancias -causas sobrevenidas y eficientes de aquellas mutaciones- y dependen del transcurso del tiempo y de las contingencias de los espacios físicos que facilitan su diagnóstico. Los presupuestos ideológicos también están en pie de guerra y ganan terreno -diríase que calurosamente- desde la aparición formal y solemne de la norma jurídica que los incorpora al nacer y no se desentiende de su acompañamiento. Se dispone así del auxilio que requieren las predilecciones y/o los valores elegidos para esclarecer la tutela de los intereses generales -amparados por esta revisión continuada- y el futuro compuesto de las peripecias que ayudan a ennoblecer su reflexión.

La impregnación ideológica de las leyes admite varios grados de intensidad dogmática o adhesión a los cuerpos de doctrina con los que esas comu- 
nicaciones se entablan. Los resultados conseguidos y el definitivo entendimiento del mensaje de la legislación -por unilateral y abrumadora que parezca su carga ideológica- dependen también de las operaciones de acondicionamiento constitucional que lleve a cabo la jurisdicción ordinaria, aunque no sea cuantioso el número de casos en que las emprenda. Procede hacerlo cuando, sin resultado positivo, se haya agotado la diligencia consistente en servirse de los criterios hermeneúticos que -razonable y no arbitrariamentepermiten otear la salida a la duda pendiente. El juez ordinario tiene que resolver, por propia autoridad, las dificultades relativas a la inconstitucionalidad originaria que contempla el art. $163 \mathrm{CE}$ y, sólo si su esfuerzo interpretativo fracasa, promover la cuestión de inconstitucionalidad correspondiente. Misión de la jurisdicción ordinaria es contribuir a la tarea de purgar el ordenamiento jurídico de las impurezas que empañen la transparencia de la legalidad fundamental. Ha de acudirse al elemento interpretativo contextual -que el constituyente difunde a todos los sectores del ordenamiento jurídico y, como tal, pone a su alcance- o ejercitar, difusa o inmediatamente, el control de la constitucionalidad de las leyes cuestionadas. Así lo dispone el art. 5.2 y 3 LOPJ (Ley Orgánica del Poder Judicial de 1 de julio de 1975)

La toma de partido -más o menos visible- y la agresividad ideológica dominan la ejecución y el signo de estas actuaciones. No es el momento de reflexionar sobre cómo casar la posibilidad -palmariamente derivada del art. 159.4 CE- de que los jueces constitucionales se afilien y militen en sindicatos o partidos políticos, con la independencia e inamovilidad que el mismo art. 159.5 CE les exige. La objeción se irá agravando más temprano que tarde. La comparación de este precepto con el art. 117.4 CE es esclarecedora al respecto. No lo es menos el spiritus mobilis con que art. 159.1 CE autoriza el pluralismo adhesivo que se infiere de su redacción. Ejemplos notorios testimonian el uso político del Derecho que la rigidez punitiva de la justicia constitucional ha empleado con una jurisdicción ordinaria que no ha defendido sus atribuciones específicas con la energía que era de esperar. Cuantos, con la curiosidad y detención que el análisis del fenómeno reclama, se han tomado el enojo de internarse en su dédalo de luces y sombras, corroboran las ideas que acaban de exponerse.

Es dable que el legislador-consciente del deber de extender el haz de sus preferencias ideológicas, si, al amparo del art. 1.1 CE, lo permite el impacto numeral de las obligaciones naturales del pluralismo político- incurra en abstenciones intencionales y/o enfáticos silencios. Unas y otros obedecen a propósitos útiles y, en menor medida, especulativos, cuyas razones últimas se captan con sentido de responsabilidad y conocimiento de causa. Las normas jurídicas también se esclarecen con datos extrínsecos que, aunque ambulantes en la periferia del mensaje de sus proposiciones, no sólo son notables o de algún provecho, sino indispensables para forjar la más completa de las comprensiones adheridas a un abanico de alternativas razonables. No en 
vano es éste un parecer indisociable de los escenarios y el cultivo de las ciencias del espíritu. Las normas jurídicas cobran una dimensión que -gracias a un criterio de interpretación auténtico y plasmado en la elocuencia del silencio que se oye- proceden de conductas significativas que, aunque secundarias a primera vista, terminan mostrando su fuerza de irrupción. Lo hacen, si -al producirse los cambios históricos y crecer las demandas de sensibilidad para encararlos- su rejuvenecimiento saca de apuros a un Derecho objetivo que vive trances desconcertantes y confusos.

Llegan también las ocasiones en que se advierte la voluntad legislativa de adjudicar, sin duda alguna, a esos silencios el valor que les identifica y hace audibles. La integridad de su conocimiento da idea del vacío que se ha diagnosticado y falta de colmar, aunque su eficacia -fruto tardío de un enmudecimiento que, dejando de ser silencio voluntario, deriva en locuacidad diferida- sólo se adivina cuando se concretan las consecuencias a que, desde un principio, aspira la voluntad del autor de la norma jurídica. Voluntad que plantea los enigmas de una versión ininteligible o cuestionada.

\section{MUDANZAS REDUCTORAS DE LAS IDEOLOGÍAS}

Antaño era pacífico que, sin disfraces ni verdades a medias, los asentamientos ideológicos se delimitasen gracias a la certeza de sus elementos diferenciadores y a las posturas de una concurrencia que confirmaba la actitud de sus opinantes y ejercientes. Al poner en negro sobre blanco la lista de sus antagonismos, se declaraba lo irreconciliable de los respectivos cuerpos de doctrina y se rehusaba la transacción o el armisticio.

La consigna de la esencial enemistad -clave para el entendimiento conceptual de lo político y, con toda su carga de aridez, fuerza motriz de lo que la política tiende a ser y significar- se extiende a las divergencias del pensamiento y de la acción, porque la colisión de los entendimientos y actitudes pone esa hostilidad de manifiesto. De ahí, la proscripción del amor a la verdad, pues la mentira, en vez de liberar, se suma a la violencia que fomenta la aniquilación de los cuerpos y el ruinoso empequeñecimiento de las almas. La degradación del juego limpio se presenta como la enfermedad más desazonante y dolorosa de cuantas aquejan a las controversias políticas. La impresión de este axioma -combatido, sin éxito, por simulaciones de vergüenza moral - se ha intentado relativizar o desteñir astutamente, pero su saña ofensiva es tal que, ante la eventualidad de acatarlo, retorna con una virulencia que se adueña de las personas que le rinden culto y de las conductas en que cristaliza.

El analista inmunizado y prevenido contra el mal de los voluntarismos, se cerciora de que los rasgos fisiognómicos de las ideologías se redistribuyen y se recomponen en planos que, ensombreciendo una separación tajante, toleran -desconcertando más aun- unos mínimos de contención movedizos y 
elásticos. De ahí, se pasa a las mutuas injerencias que abundan en los campos minados de lo confuso y lo inauténtico, donde las paternidades ideológicas se difuminan o reivindican ámbitos que nunca fueron suyos. La oferta individualizada de las ideologías clásicas, se alimentaba de valores que, elegidos escrupulosamente, soportaban una apropiación exclusiva y resistente a la tentación deformadora que la discutiera o privara de sus atributos. Esta acumulación absorbente llevaba a dominar la concurrencia que, en términos afines de indivisibilidad y monopolio, ejercía el resto de las ideologías. Era improbable - puesto que el falso amor a la verdad tiene más de dogmatismo rudo que de contacto sugestivo y amable- que dos o más parcelas de acción y/o reflexión compartieran, sin diferencias ni contradicciones, un cuerpo permeable de doctrina. Moderar los prejuicios de exclusividad intransigente era recomendable para acortar distancias y frecuentar, en homenaje a la verdad, las zonas más respetables de los convencimientos morales. Una coaceptación tempestiva, no recelosa y tardía, habría aproximado a los resultados elogiables, a las tareas definidoras de los intereses generales y al conjunto subrogado de la noción tradicional de bien común- de los dictados de la coexistencia, la colaboración y la participación. Siempre se echan de menos, a deshora, la inteligencia y la generosidad imprescindibles para esclarecer y no enturbiar las brumas de ese panorama. La reducción de las diferencias ideológicas y su sustitución por ofertas de contenido variable se proponían desde frentes distintos y, a primera vista, tan explicables como sorprendentes. Confiaban en las alianzas de una salvación coyuntural que evitase la disolución de las totalidades ideológicas o su reversión a procesos degenerativos de incertidumbre y de abandono. Parece que las ideologías sobreviven gracias a retoques tenues, cuyas pretensiones de modernidad -inseparables del propósito de quedarse ahí- perduran, al menos de momento, y contribuyen a salvar el mensaje que se recupera o reinterpreta. Los imperativos del mercado así lo dictan para bien y para mal de cuantos corren estas aventuras. Suya es la carga de ofrecer estímulos que repongan la energía de las voluntades -ávidas de solidaridad y cohesión-y restauren la devoción de los entendimientos. Las adhesiones se entienden con las servidumbres y reservas que suscita la ocupación de unos espacios doctrinalmente comprimidos y con escaso margen de maniobra, allí donde hace falta apurar las operaciones de concentración -conceptual o filosófica- que, sin ser obligadamente cotidianas, tienen mucho o casi todo que ver con el buen fin de los proyectos emprendidos.

\section{SERVIDUMBRE Y GRANDEZA DE LOS CAMBIOS IDEOLÓGICOS}

El esteticismo de las ideologías y sus técnicas de reclutamiento mostraban los claroscuros y retos llevaderos a que sus simpatizantes y/o adheridos 
resolviesen ganar, acatando sus postulados y sin un excesivo culto al juego limpio, la batalla de sus predilecciones. El magisterio de la Historia -que, pese a lo aleccionador de su didáctica, no escarmienta a los más o menos avisados, ni evita los tropiezos de la condición humana en la misma piedra con que se lastimó por vez primera- declara que los combates librados y las victorias logradas por las ideologías no han ido más allá de los campos en que -con los errores y prejuicios temibles- frecuentaban opciones de signo muy diverso. Formaban parte de ellas los artificios introducidos a sabiendas de su naturaleza delirante, los aventurismos hueros de creatividad, las deformaciones ofensivas de las verdades históricopolíticas y los pensamientos de deseo cuyo depósito se transmitía, en clave fundamentalista, a las comunidades de afines que se los apropiaban.

Los agentes de estos experimentos confiaban en que, con el tiempo y un tanto de fortuna, la excelencia ideológica -triunfante en los círculos de competitividad- prevalecería sin disidencias ni fisuras. No faltaba la previsión prudente de que, si se daban defectos gruesos o fracasos notables, la empresa ideológica se desbarataría por falta de apoyo para continuarla. Sus mentores abdicarían - con el coste del descrédito políticosocial- de unos fines inviables o sin los alicientes anejos al pronóstico de darlos por cumplidos, en un futuro próximo, e invitar a compromisos excluyentes de su consecución. Las ideologías -oteadas, desde la perspectiva de sus contemporáneos, como la expectación apasionada de un sugestivo porvenir- podían acusar y/o asimilar los lastres de su devaluación o los fracasos del programa que exageraba unas promesas imposibles o de costoso cumplimiento.

El óbito de las ideologías viene de su impotencia para contrarrestar los alegatos -reiterados y acérrimos- que, de adverso, se entregaron a desacreditarlas. Defendían que las acciones políticas -dependientes del cuerpo de doctrina de las ideologías- se legitimaban, a la luz cegadora de la filosofía del éxito, por lo palpable y duradero de sus respuestas a las demandas sociales. Se les negaba la bondad propia de las ilusiones o atractivos que, de entrada, seducían y se desvanecían a la larga. También cundió el convencimiento -que, al irse cargando de razones, colonizaba la conciencia común e individual- de que la pureza de los principios ideológicos cedería a los apremios de una competencia multiplicadora de sus obstáculos de origen. Lo caduco de las ideologías no tanto ha resultado de su desalojo por las acciones hostiles -de gran envergadura- tendentes a su desprestigio, cuanto del convencimiento de que, ante la rapidez de las mudanzas ocurridas, envejecerían y se desplomarían demasiado pronto. En vez de asistirles un prolífico mal de crecimiento, han soportado una existencia carente de arrestos moralizadores y de recursos aptos para actualizar sus contenidos variables.

Perdidas las oportunidades de una renovación persuasiva y fecunda, las ideologías químicamente puras han capitulado ante sus adversarios más tenaces. Han cedido sus ámbitos de origen a los sucedáneos ideológicos que 
-para eximir, a quien cupiere hacerlo, de la funesta manía de pensar-cifran sus cualidades en la fogosidad de sus argumentos acríticos y publicitarios. Su difusión dispone de un aparato divulgador de propuestas cómodamente inteligibles para no vejar a sus destinatarios ni causar la impresión de que su capacidad de asimilación se menosprecia. Se distingue también por el dogmatismo intransigente que prohibe relativizar esos mensajes o alejarse de su inspiración elemental.

Era pacífica la tesis de que, como convenía al decoro de las ideologías, la salvación secular de las personas y los grupos sociales dependía del tino con que sus agentes seleccionasen la opción más conveniente al pluralismo de sus ofrecimientos. Hoy, nadie objeta que los prejuicios y el simplismo dialéctico de muchos ideólogos - más culpables de indigencia creativa que de sobriedad de pensamiento- dificultan, por no decir que impiden de raíz, rehacer las más valiosas de esas variedades y situarla en un mercado de consumo competitivo y abierto. Manejan vestiduras superficiales o disfraces de lugares comunes que, sin agravar el esfuerzo intelectual de su hallazgo y oferta, tratan de hacerse digeribles con inconsistentes aderezos. Reiteran, como condición de la prosperidad de su industria, la máxima de que a la salvación secular no se adviene sin acatar esas novedades. Las adhesiones muestran lo inflexible de un acto de fe que -al excitar las fobias peculiares del miedo a la libertad - impide un discurso sosegado y una censura seria de sus motivaciones. La interdicción de discrepar pertenece al depósito intangible de las ideologías que así se desfiguran y propagan. Encarna un rasgo existencial de lo que, desde la especulación de los teólogos juristas del siglo XVI, supusieron los ciclos de las formas - rectas y corruptas- de gobierno y participación activa en los asuntos sociales y políticos.

\section{REACCIÓN DE LOS ORDENAMIENTOS JURÍDICOS FRENTE A LOS CAMBIOS SOCIALES Y POLÍTICOS QUE HAN DE SOPORTAR}

La nota de irreversibilidad que, al realzar su prestigio, se atribuye a la autosuficiencia de las ideologías, ciega los atisbos o apaga las intuiciones que, ante lo sospechoso o esotérico de algunos de sus ofrecimientos, no desiste -como cumple a lo saludable de toda pesquisa intelectual- de buscar la sedación de la verdad liberadora. Esa obstrucción -que, a primera vista, parece intransigente con las frustraciones de los errores advertidos- sólo elimina en parte las insuficiencias que, minorando la velocidad de crucero de las empresas ideológicas, vician la calidad comprensiva y la estima social de su recepción. Así se explica, sin justificarse ni de lejos, el arrojo con que sus mentores acumulan un copioso dictado de máximas de supuesta rectificación y puesta al día. Su aceptación reclamaría -para completar el bien de la causa ideológica y satisfacer moralmente a sus adeptos- una sinceridad crítica exenta de trabas. En definitiva, un compromiso con la depuración de las ver- 
dades en que dicen fundar su calidad y rehacer un mercado ideológico consecuente con los propósitos de enmienda y engrandecimiento.

Un ordenamiento jurídico que, habituado a la reiteración de esos obstáculos, cuida de removerlos o de salvar su imperfección, causa la impresión demasiado inequívoca y unilateral -pues las cosas vienen a ser así y no de otra manera- de asociarse a parcelas ideológicas de rotulación inconfundible. Nunca es tarde para eliminar la identificación con unas preferencias que se robustecen cuando se han despejado -ontológicamente y no al convencional amparo del consenso- las incógnitas que preceden a un asentimiento agotador y convincente. Es razonable y continuista la lógica con que las proclamaciones constitucionales manejan las premisas -normativistas y exentas de connotaciones axiológicas - que encarecen la fidelidad del legislador ordinario a la ordenación fundamental del Estado social y democrático de Derecho, el sometimiento pleno del poder ejecutivo a la ley y al Derecho - ¿cuasinatural?-que la inspira, y la sumisión exclusiva -clave eminente de su independencia- de los jueces ordinarios al imperio de la ley. Así lo entienden y subrayan los arts. 9.1 y $3,103.1$ y $117.1 \mathrm{CE}$. Un ordenamiento jurídico cuyas experiencias históricas aleccionan sobre esos riesgos de unilateralidad y no se toma el enojo de alejarlos si no puede eludirlos de momento, derrocha-diríase que pecaminosamente- las oportunidades que tiene a su alcance. Siempre hay tiempo de identificarse con el sistema o complejo ideológico más cercano a las preferencias pluralistas de la sociedad. Todas ellas de obligada consideración para graduar la adhesión del constituyente a un cuerpo de doctrina fijada o espectro dogmático que incorpora las garantías comunes a las formas de organización democrática de la sociedad en el Estado de Derecho. Estado que, tras hacer balance de las particularidades del cuerpo social, dispone lo más conveniente al futuro que sugieren esas averiguaciones .

El análisis de las ideologías se resiente del mal que la crítica -¿competitiva o distributiva?- asigna a su pasado y a los escarmientos que datan de sus experiencias. Cada bloque de remedios pensados para enmendar esos defectos, es tan heterogéneo respecto de los otros -llamados a preservar los residuos ideológicos que, a punto de hundimiento, demandan su auxilio- que hace muy cuesta arriba resumir las peculiaridades empíricas que, una vez comprobadas, no se corresponden con las diferencias específicas apreciables a partir del género próximo sobre el que se trabaja. Incumbe a la política-de cuyos postulados menos gratos y dignos de elogio forman parte la proscripción de la excelencia filosófica y el elogio de ciertos imposibles- intentar esa síntesis. La hipoteca de unas premisas poco aseadas favorece lo desedificante de unas reconstrucciones ideológicas más propensas a conquistar espacios útiles que a sondear los mínimos de las verdades debatidas. De ahí, la imagen -tan elocuente como digerida por el antiacadémicismo popular- de los casos en que la política encama en un lecho común a los agentes de orientaciones ideológicas opuestas. Se han inventado soluciones que -combinando lo su- 
rrealista y lo esperpéntico- acusan arrestos inversamente proporcionales a la voluntad de avergonzarse de su mezcolanza. La puesta en escena de esas deformaciones evidencia una imposibilidad moral y políticamente dramática, aunque respaldada por la terquedad -que no es energía conforme a razónde la mala conciencia. Su proyecto exhibe un síndrome de irreductibilidad y muestra las posturas -intransigentes y dogmáticas- de un ostentoso triunfalismo que no borra sus engaños y debilidades.

El alza de sus insuficiencias y lo frecuente de sus claudicaciones -elementos competitivos del mercado ideológico- no fomentan una cultura de la reflexión socrática y del cambio que cabe esperar, sino que se apela a los viejos depósitos de las ideologías. Reza uno de ellos que, a semejanza de las promesas sobrenaturales de los fines salvíficos, el óptimo de las aspiraciones seculares -esto es, el bien común que abarca los requerimientos de la coexistencia, la colaboración y la participación, además del cuidado de los intereses generales y la satisfacción de las demandas sociales-no se concibe al margen de su tradición, sus objetivos y sus lemas. Es entonces cuando la libertad del decisionismo políticolegislativo - que encaja en la cláusula del art. 9.2 CEdebe ejercitarse con la ductilidad que esas oportunidades le otorgan. Ninguna de sus opciones razonables -inherente a la condición de disciplina del espíritu que el ostenta el Derecho- puede coartarse por un hipotético poder de monopolio o absorción de otras ideologías concurrentes.

\section{5. ¿CÓMO ACAECE Y TOMA POSICIONES LA ROTACIÓN POLÍTICA DE LAS IDEOLOGÍAS?}

La identificación del Derecho con el mínimo de moralidad reconocida y practicable en las comunidades que se le someten, sólo se ha superado, que se sepa, por la cláusula espectacular en que el art. 1.1 CE autoriza a incluir un bloque de moralidad legalizada en el interior del ordenamiento jurídico. Se oculta -tras este aserto de resonancias bíblicas, porque su yugo es suave y su carga ligera- un pacto social que, sin título expreso de renovación, sugiere, como norma de acción de buen gobierno, la rotación política de las ideologías. Sus oportunidades de acceder a los pagos del Derecho constituido no pueden desdeñarse ni pasarse por alto al tiempo de exigir que sus principios impriman carácter al ordenamiento jurídico que los hace suyos. Hay petrificaciones ideológicas cuya calidad avala su efecto positivo y les refuerza para subsistir -frente a las incursiones de otras ideologías incidentes en su cuerpo de doctrina- cuando, cambiando de rumbo, el Derecho constituido acepta ingerencias agresivas o concomitantes. Ello sucede si el ímpetu de la ideología va más allá de la disposición -mínimamente coordinada y armónica- de las predilecciones que antaño compartieron los programas de los reformadores sociales. Un reto que, luego de aceptarse, puede abocar a consecuencias estériles y padecer las amarguras del fracaso, o 
acelerar la asimilación de las innovaciones. Del posible inventario forman parte las ideologías deletéreas o los proyectos antagónicos -no en vano, las reglas de oro de la política canonizan la máxima de un contacto hostil e inamistoso de sus protagonistas- que, sin aptitudes creativas, resucitan las posturas hostiles y desandan el corto trecho que han ganado unas coincidencias muy rudimentarias. La izquierda se denomina unida para negar las dispersiones y estados coyunturales que revelan su desintegración de fondo y estado de conflicto.

Los constituyentes de los países civilizados y los agentes o poderes sociales que tropezaron con esas arideces, aprendieron pronto y bien la lección de que lo mejor era enemigo de lo bueno. Al erigirse el Estado de Derecho liberal burgués, el óptimo ideológico dejó de ser un orden natural minucioso y casuístico, cuya invocación era estéril a la hora de verificar, como expresión de su respuesta, que lo variable de sus orientaciones y de los principios en que descansaba, lejos de procurar certidumbre, abundaban en inseguridad y escepticismo. Los mínimos del orden natural, de los que nadie disentía, se vaciaron en las cavidades de un Derecho escrito que - presumiendo la bondad de sus reglas y defendiendo su positivización- se legitimaba por la voluntad del pueblo, titular originario o en raíz de la soberanía política y organizador mediato de la sociedad en el Estado demoliberal. Aun a riesgo de que, cómo ocurrió en más de una ocasión, esa voluntad abrigara propósitos confusos o revelara errores de diagnóstico. Las complicaciones surgieron cuando la validez del refrendo soberano -título del ordenamiento jurídico que se inauguraba y de las medidas de su Derecho positivo- perdió, por decirlo de algún modo, el encanto de su inocencia original. Su sobriedad sufrió la impronta de las diversidades axiológicas que provenían de la reflexión sociopolítica aireada en el seno del Estado demoliberal- y de las tentativas, radicales o tenues, de sustitución de sus modelos.

Las elecciones ideológicas se distinguían por la cosmovisión absorbente de sus objetivos monolíticos y la difusión de un pensamiento de deseo dispuesto a demoler cuantos intereses y/o diversiones especulativas paralizasen el buen fin de las respectivas ofertas. El Derecho incorporó -sin digerir a fondo muchas de ellas- propuestas ideológicas que intencionadamente soslayaban las perspectivas integrales de la sociedad, a la que aseguraban servir con entusiasmo, y relegaban a un segundo plano, cuando no descartaban, ciertos aspectos - generalizadores y básicos-del bienestar social. Aunque, a primera vista, adoptaban severas posiciones morales, acreditaron pronto su ineptitud de síntesis, no tanto para neutralizar el advenimiento de los radicalismos adversos, cuanto para identificar las ofertas adeudadas a una familia humana estabilizada, portadora de irrenunciables intereses, fruto y modelo de una racionalización inteligente. El tiempo -que templa lo cáustico de las ideologías y lima lo áspero de sus intransigencias- persuade de que el bienestar individual y social pasa por el retorno a la prescripción de hacer el bien 
y evitar el mal, porque sólo la devolución a los orígenes depura la fragilidad o los abusos de los dogmatismos ideológicos.

Cuando el vacío del silencio - que se oye en los espacios atrapados por las ideologías- registra la devaluación o el abandono de las viejas motivaciones o consignas, el voluntarismo del Derecho interviene para adueñarse de esas oquedades. A medida que surgen las dificultades, las adquisiciones ideológicas ceden su lugar a proposiciones reductoras que, reteniendo aspectos residuales de las promesas rotas, sugieren fórmulas prosaicas y no exentas de nostalgia por lo que ya es inaccesible a las demandas del mercado ideológico. Hay una descarnada realidad que, deteniendo el avance de las ideologías, las degrada más rápidamente que lo que cabe temer de sus espontáneos desmayos. Algunos de ellos - valga, como modelo, el testarudo augurio del fin de la Historia - ingresaron, por derecho propio, en la crónica de la estulticia humana, añadiéndole los componentes que hicieron fracasar su experimento.

¿Pueden rescatarse los mínimos de emotividad ideológica en momentos marcados por la voluntad de que se esfume el rastro de las ideologías? El crecimiento de las apetencias de bienestar contradice la austera filosofía burguesa - de cuño protestante- que primó la excelencia de la austeridad y el sacrificio. Hay cierta consecuencia con la idea de que quien no vive, en su acepción más gratificante y comprobable, no se redime nunca ni consigue las dosis ansiadas de liberación. Al romanticismo político de las orientaciones ideológicas subyacen deseos voraces e insaciables, cuyas premisas de satisfacción reducen a lo indispensable - para no empañar el crédito de su imagen- los elementos de desinterés y de altruismo. Hay una propensión a la mudanza y una intencionalidad de cambio que, bajo las apariencias de la renovación ideológica, provocan distorsiones -acordes con las servidumbres anejas al ejercicio del poder- que desisten de sus aspiraciones de excelencia o admiten más defectos que los indulgentemente tolerables.

\section{ACCESO A LA IDEOLOGÍA DE LO JUSTO}

Es necesario un arriesgado paso que el Derecho ha de dar sin acudir a los tópicos recursos axiológicos, aunque, a falta de otras motivaciones, recobre alguno de sus compartimentos. La indiferencia básica -que autorizaba decisiones políticas del más amplio espectro- se conmueve ante un desafío cursado a todos los ámbitos de la sociedad en que, frente a la proliferación de las desigualdades e injusticias, abundan la vulgaridad y el conformismo. No es del caso apelar a cuerpos concretos de doctrina, compendios de valores o etiquetas de repentina apropiación. Se requiere una oferta sugestiva y elástica, que, a invitación de los más recientes signos de los tiempos, induzca a cooperar con sus adquisiciones y adelantos. Saciar el hambre y la sed de justicia -que por doquier se han extendido- es el reverso del imperativo que manda edificar el bien y evitar el mal. No se trata de dar con nada nuevo 
- ¿quién no desearía encontrar oportunidades residuales para ejercitar una creatividad de ese carácter?-y sí de rescatar parte de unos valores que inexorablemente están ahí, porque fluyen de continuo y no ceden a las conminaciones del olvido. Sin elogiar aparatosamente la etiología filosófica del retorno y de sus fundamentos doctrinales, se rescataría - gracias a una convicción efectiva y nostálgica- un orden natural de contenido variable, cuyo progreso atañe a toda sociedad que anhela sentirse transformada.

Tal es el asidero a que se acoge el art. 1.1.CE en un rapto secularizador que enfatiza la voluntad salvifica del orden natural. Sin desvelar las premisas ideológicas ni el verdadero rostro de sus predilecciones, las está conectando con la ideología de lo justo. Se propugna la vuelta ambiciosa del ordenamiento jurídico a los compromisos que, ordenados por la recta razón, intelectualizaban las soluciones del Derecho objetivo. El valor superior de la justicia -que, situado dentro del ordenamiento jurídico, no es una potencia extrínseca que le comunica, por ósmosis, lo que puede de si misma-sintetiza la igualdad de opciones individuales y colectivas, y la libertad -civilizadamente restringida- que requiere su consumación. Para rejuvenecer la justicia y facilitar sus expansiones, se abre un camino cuya ruta - evocadora de la inquietud agustiniana- despierta las curiosidades que dimanan del aliciente intelectual y emocional de su mensaje. Superando la concepción modesta del Derecho, el orden nuevo - que va a surgir del mismo- deja de residir en los mínimos éticos a que se resignaron sus definidores y se concibe como el óptimo de rectitud moral que impregna los mandatos y prohibiciones relativos a los intereses generales. Se rompe con la continuidad imperante desde que el positivismo legalista destruyó la confianza en los postulados del orden natural, objetando lo ilocalizable de sus fuentes, lo polémico y evanescente de sus contenidos, y la ausencia de sanciones que asegurasen su efectividad. También se cuestiona el criterio de validez consistente en asignar a las normas constitucionales el carácter de reglas hipotéticas y fundamentales que conservan enhiesto el ordenamiento jurídico e impiden su dislocación. Sólo un acto de fe en esa validez permitía la supervivencia del sistema y la atribución de la solidez que la garantizaba. Se daba así por buena la delegación en los poderes públicos de la soberanía que el art. 1.2 CE reconoce al pueblo en calidad de titular originario.

La ideología de lo justo remedia la evaporación o, si se quiere, el desconcierto de las ideologías deprimidas y dispersas, cuyo empobrecimiento se advierte cuando hay que afrontar inaplazables objeciones o animar las conductas propicias a los mensajes difundidos entonces. A las ideologías especiales, competitivas y marcadas por la unilateralidad de sus programas, secundadas por incondicionales afecciones e inexpertas en el cultivo del espíritu crítico, sucede la oportunidad -universal y seductora- de sumergirse, cerca del pluralismo que está en el horizonte, en las peripecias de una vida que se dice aceptada conforme a justicia. El recurso a este concepto indeter- 
minado - moral y jurídicamente- sitúa en la línea de salida de unas aventuras que no llegarán lejos si sus afanes de cambio se congelan y, como complemento indispensable, no se apresuran a desterrar los estorbos de la hostilidad intelectual gratuita, los intereses espurios y la envidia igualitaria.

Lo novedoso del art. 1.1 CE permite que el Derecho constituido elija, para acomodarlas normativamente, cuantas políticas puede ofrecer, con legitimidad, un programa específico de legislación y de gobierno. Todas se benefician del espíritu y finalidad que regeneran los ingredientes -utópicos y estimulantes- de cualquier ideología utilizable para plantear sus demandas de renovación y sortear los males que amenazan a sus oportunidades más preciadas. ¿Por qué sucede así? La respuesta ofrece dos aspectos.

Se presupone que el art. 1.1 CE está comprometido, a toda costa, con la causa de un Derecho justo, pues huelgan sus invocaciones -más debidas a la emocionalidad circunstancial que al rigor metodológico- de la igualdad y de la libertad. La apelación a la justicia condensa los contenidos respectivos de una y otra, y la mención del pluralismo político insiste en la presencia de una variante notable de la libertad. Un criterio contextual y sistemático de interpretación -que luce en el art. 9.2 CE- aclara que la elevación de la sociedad a un conjunto de grupos erigidos y ordenados conforme a justicia, requiere siempre defender los valores superiores de la igualdad y de la libertad, suprimiendo cuantos obstáculos disminuyan o erosionen su plenitud consustancial.

La otra proposición tiene un alcance que extravaga del usual contenido de las normas jurídicas, destinadas a construir proposiciones deontológicas ajenas al mundo sensible y típicas del mundo del valor- que se resisten a incluir hechos históricos -identificados, cuando menos, por los accidentes del tiempo y del lugar-o realidades sociales que, pese al relieve que se les otorga, se reducen al sustrato -que se presume y reconoce- del supuesto de hecho descrito en su imagen rectora. No hay razones de peso para alojarlos en formulaciones generales que sólo acogerían las conclusiones abstractas que cierran el proceso generador de la norma jurídica puesta en circulación a la espera de sus experiencias. El art. 1.1 CE defiende que el pluralismo político recibe su favor y su crédito de la naturalidad con que lo atisba una norma constitucional que, en parte, recuerda la ocurrencia del pasado histórico, y, en parte, pronostica el que, así las cosas, puede ser el futuro esperado. El homenaje rendido al valor superior del pluralismo político da fe de que arrecia la aspiración de la añorada convergencia para resucitar las ilusiones ideológicas que unos consideraban parte irrecuperable del pasado y otros trataban -diríase que numantinamente- de mantener erguidas al precio de una supervivencia poco gratificante. Ahora se intuye -con el fervor surgido de las restauraciones ideológicas que se divisan- la opción de acceder a una cautivadora ideología de lo justo y constatar su productividad social. Aun cuando -algo desafiante y enigmáticamente- se cuestionen los rasgos definidores de 
esa justicia óptima y subsista el debate que, para resituarla, propugnan cuantos salen valerosamente a su encuentro y, a la usanza de la vieja actitud filosófica, se dejan cautivar por lo portentoso de las verdades que insinua y el desafío de los compromisos que acarrea.

Gracias al pluralismo político, el Derecho constituido se abre a las oportunidades -que siempre fluyen y renacen-de un discurso ideológico que, a causa de sus expectativas de futuro, no mengua ni se empobrece prematuramente. Entraña un ejercicio intelectual exigido a las personas y grupos sociales autorreguladores de sus libertades, descubriendo los campos-ocultos hasta entonces- de su contenido esencial y ampliando sus expresiones periféricas. Las filas de los actores del nuevo pluralismo se engrosan con la contribución de cuantos - a la voz de un paso al frente del art. 1.1 CE- hallan en su mensaje las claves de proyectos que no se ultimaron y que se reanudan al amparo de la consigna transformadora y social del art. 9.2 CE. La reideologización de lo justo aporta sugerencias cuya prosperidad va a depender de la solidez de las condiciones intelectuales y morales que -sabedores del riesgo social de su aventura- se aprestan a correr cuantos aprovechan la ocasión ofrecida. Pese a la indeterminación de la cláusula que constituye su asidero, no les arredran los reparos con que el pavor o la apatía pueden asaltarles. Así se esbozan las sendas axiológicas que, reduciendo las indeterminaciones conceptuales, van a trazar unos reformadores sociales merecedores de este título, devotos de la verdad, respetuosos con la naturaleza de las cosas y dispuestos a rebajar las indigencias y las cotas de miseria que aquejan hoy a buena parte de la familia humana.

Es entonces cuando se otea el panorama abigarrado de interrogantes que lo pueblan. Se pregunta hasta dónde esa cláusula-que rehabilita los objetivos recurrentes del orden natural- invita a seguir adelante, contra viento y marea, y a implementar las iniciativas de progreso que le son inherentes. Se cuestiona la medida en que favorece las promesas y pactos sociales conducentes a la revolución desde lo alto, en que los poderes públicos conjugan los controles del Estado social y democrático de Derecho y las bondades residuales del despotismo ilustrado. No pierde de vista los posibilismos de esta revolución. Se discute, en fin, si su mensaje lleva tan sólo a prescindir de su frondosidad, a desistir de analizar voluntariosamente los capítulos de sus ofrecimientos y a suplantar la que debe ser una veraz respuesta - razonada y convincente- por otras plagadas de lugares comunes a que se acude sin precisión y sin escrúpulos. Tópicos que, para mayor afrenta de la opinión pública, alardean de sus operaciones de funambulismo como quien se jacta de la más ingeniosa de las ocurrencias. Allí donde el encanto de la genialidad brilla por su ausencia, la propaganda -emuladora de los modelos autoritarios fenecidos-sigue sirviendo a los embaucadores que acreditan, con creces, su ineptitud para entender lo que es y significa un auténtico esfuerzo de transformación. Lejos de asumir la responsabilidad de su elección, reiteran - con la monotonía propia 
de su esterilidad-criterios o reglas de acción que, sin añadir nada nuevo a lo ya conocido, rebautizan -como si de un curioso hallazgo se tratase- consignas cuyo maquillaje no logra ocultar que ya pertenecían a los depósitos del saber y al patrimonio cultural.

No es esto lo menos censurable. La difusión y, en su caso, la detestación o el elogio de lo que aportan estas supuestas novedades, no es comúnmente la tarea de una minoría encargada de la puesta al día y la transmisión didáctica del pensamiento, porque, entre otras razones, la reiteración de su doctrina da muy poco de si. Los medios de comunicación divulgan la crónica de su conexión con el pasado y, al hacerlo con escasa fortuna, adolecen de imprecisiones y lagunas que prestan un flaco servicio a la causa de la verdad histórica. La reseña de esos antecedentes -casi siempre incompleta y mal documentada- se somete al método de sustituir el enunciado de los principios básicos y sus análisis, por adiciones marginales o evocaciones anecdóticas.

¿Dónde anida la idea de justicia que, ante la indeterminación conceptual que la empaña, responde al reto con que la ideologización de lo justo clama por sus fueros? Lo justo coincide, así las cosas, con lo positivamente afianzado y adquirido en virtud de una opción que atribuye a la acción ordinaria del constituyente la virtud de agotar la regulación de cuantos aspectos del orden natural se atisban en el horizonte constitutivamente histórico de la razón práctica. Ello es tanto como diagnosticar las exigencias de interés general que predicen su advenimiento o que desde ya requieren atención. Avanzando una primera hipótesis, el art. 1.1 CE pretende -ya que no se le veda el elogio de la acción constituyente- erigirse en crítico de su propia actividad y destacar la perfección de la obra constitucional relativa a la estructura del Estadoordenamiento y al decoro del Estado-comunidad.

Se ha de presumir justo todo aquello que la solicitud del legislador constituyente-celosamente crítico al depurar los materiales acopiados- ha llevado al acervo de los principios y preceptos de la legalidad fundamental. El propósito -seguro de su exactitud y convencido de su acierto- ha chocado con las consecuencias de la gestación transaccional -es decir, por consensode la carta política, algunos de cuyos pasajes se apartan de la línea de fuerza marcada sus progenitores. Justo es, desde esta perspectiva, lo que no puede preverse ni llevarse a buen fin con más esmero y perfección que los logrados cuando se garantiza la real y efectiva -todo lo contrario de platónica y escuetamente eficaz- tutela de los bienes jurídicos que integran los intereses generales. Justo es también lo que - dada su coincidencia con las coyunturas y el peso específico que, según las circunstancias de las personas, del tiempo y del lugar, enseñan las realidades sociales- considera aceptable una opinión pública que retransmite las aspiraciones de que ha tomado buena nota. Cada realidad social es una variable que -gracias a la participación, voluntaria y exenta de trabas, de las personas y grupos intermedios que vertebran la sociedad y la mantienen erguida para obstar a su disolución- obliga a reflexiones 
de interés general -distintas de los traumas de corte doméstico-que el ordenamiento jurídico asocia a sus prohibiciones y/o mandatos, ponderando de su trascendencia y adecuando las líneas de pensamiento a las condiciones en que ha de actualizarse su discurso.

La aprehensión de la justicia implica que cada bloque o acervo ideológico contiene exigencias que -a diferencia del pretérito imperfecto de la vida de las ideologías- presentan demandas sociales que ninguna opción restauradora de lo justo puede desoír. Han de encararse con entereza y lucidez, sin obviar las respuestas -más o menos afortunadas y/o esperanzadoras- que su disponibilidad ofrece. Pueden darse necesidades-límite que, como exclusivas de una preferencia, no son comunes a todas las opciones reideologizantes, aunque -tal y cómo las demandas sociales se conciben y difunden hoy díano es esa la regla general. Sus hallazgos y valoraciones requieren exploraciones críticas que no incurran en la petulante actitud de subrogarse -sin experiencias previas- en la posición de quienes ejercitan aquéllas. Las demandas sociales se dan a conocer tras las invenciones o encuentros que descartan el error de las elecciones ideales o probabilistas. Son éstas lo más opuesto a lo estadísticamente previsible, practicable y fundado en las contribuciones de la Historia. La invención -que etimológicamente significa el hallazgo de lo tenazmente perseguido y localizado entre luces y sombras-consiste en aprehender algo que, aunque ya existe, acampa en unas latitudes nebulosas que frenan la ida en pos de su traza conceptual y su definición.

Una reconstrucción de este calado supera la dimensión idealista de lo justo - tan cara a la visión aristotélicotomista del orden natural- y asiente a la perspectiva realista que -entregada a su reinterpretación-gira en torno a las novedades de una razón práctica capacitada para avisar de su proximidad y enunciar las ventajas e inconvenientes de sus apariciones.

\section{HACIA UN RECOMPOSICIÓN SALUDABLE Y UN ADECUADO ENTENDIMIENTO DE LO JUSTO}

He ahí la emergencia del interrogante sobre qué rasgos ofrece una justicia aceptable con el rigor preciso para que cada nuevo sector del pensamiento edifique, por cuenta propia, su ideología de lo justo. El planteamiento del problema no se agota con el recibo de esta afirmación. A ella se suman y siguen los riesgos de la tentación deformadora o la falsificación apresurada, afluente a tesis o propuestas que, exentas de verdad convincente, causan, no obstante, una impresión de razonabilidad. Mientras no se repriman las intoxicaciones de la opinión pública con verdades a medias, vulgaridades desorientadoras y lugares comunes que se precian de una originalidad que no poseen, las demandas sociales - exigentes de una bondad que las nuevas ideologías deben asociar a la realización honesta de sus fines- seguiran cautivas de la inducción voluntarista y de la lesividad de sus prejuicios. Se volverá, con la 
seducción del simplismo dialéctico, al designio - tan excitante como fácil- de convertir en dogma lo que a toda costa se desea. Se vestirán sus desnudeces conceptuales con el manto - poroso y alicorto- de las ocurrencias del pensamiento débil. Se redoblarán las tentativas de intoxicar a la opinión pública con la obstinación publicitaria, cuyas reiteraciones aplastantes -heredadas de la desoladora propaganda marxista, sólo que acondicionadas, puestas al día, y no siempre libres de intenciones malévolas- logran lo que no está al alcance de una métodología persuasiva.

Son más irrespetuosos con las condiciones de asimilación de la ciudadanía, los términos de que hacen uso cuantos - convencidos de la oportunidad de explotar un éxito que dicen estar tocando con la mano- intentan confiscar los reductos de la ideología de lo justo que confunden con su arbitrismo intelectual y moral. Manejan una aleación de verdades de circulación algo grosera, cuya expansión depende del resultado amable y no de la delicadeza intelectual que debe asistirlas. Es incómodo y causa de vacilación acercarse a un diseño de justicia que, al mismo tiempo, resulte atractivo -como espejo de laboriosidad- y convincente, sin tachas que enturbien sus adelantos y conquistas. Si su mensaje no arroja la certidumbre sensata de lo justo, forzoso es revisarle -con conciencia crítica y sin prejuicios partidarios- para renovarle o resignarse a convertirle en uno más de los paraísos perdidos.

Cuenta también la habilidad dialéctica de quienes -despreciando la máxima que reza «si cambias hasta el punto de desconcertarme, es porque la verdad no está contigo....»-admiten que los contenidos variables y compatibles de lo justo registren colisiónes resueltas con el prevalecimiento de unos sobre otros. Frente a las distorsiones o sofismas disfrazados de propuestas elásticas, lo justo -respaldado por la fidelidad al principio ontológico de no contradicción- no puede, como cualquier otro valor o realidad celosos de su identidad, ser y dejar de ser al mismo tiempo. Hay que seleccionar y dar nombre a las realidades sociales en que se funda esa aprehensión. Se necesitan una visión afortunada -cuyo método, de feliz idea, prescinda de los abusos triunfalistas- y una constancia de que así lo sostiene la opinión de una parte de la sociedad ilustrada, en virtud de su madurez, y sana, porque sólo su recta intención se considera buena sin limitaciones. Apreciadas por los que tienen el deber de estado de reconocerlas o cumplirlas, enfrentan a las alternativas de impulsarlas, para remover ciertos obstáculos o completarlas adecuadamente, si ya se ha desencadenado su atención. En los cimientos del aparato de los sistemas democráticos se asienta el socratismo de una regla que recuerda cómo - a causa de la inclinación y la concepción naturales del mensaje que encierra- la verdad emana de la mente y el corazón del sabio habituado a discurrir en soledad. Nunca del frenesí de las multitudes que, arracimadas en el ágora, aclaman a quienes les ocultan el rostro de la verdad -temida y lacerante- y, a cambio, colman sus ansias de ceder ante la magia de las deformaciones ideológicas. 
El saludable entendimiento de lo justo se enfrenta a un vacío del que se han evadido la emotividad y fuerza sugestiva del misterio - presentes de antiguo en las adhesiones religiosas o afines- con que las empresas ideológicas reforzaban la seducción de los prosélitos incondicionales y los adeptos de segunda zona. Se explicaban así las ilusiones que encendían la voluntad -inmersa en lo conmovedor de esas vivencias- de darlo todo, incluso la vida, por el triunfo del debate en marcha y por el alza de la fe depositada en los cuerpos de doctrina que se divulgaban. Ahora bien, como los subrogados o sustitutivos ideológicos carecen del mordiente de las ideologías de pro y yerran en el relevo que ocupe su lugar, sólo resta un mercado imperfecto donde, sin visos de progreso, se agolpan ofertas ideológicas irreconocibles o depredadoras de los que fueron sus orígenes.

El peso específico de la emotividad dispensaba de un rigor intelectual que no era sostenible ni siempre estuvo a mano de las ideologías. La evaporación de la emotividad rebaja los ejercicios de especulación y compromiso ideológico a operaciones disuasorias o desprovistas de aliciente. Decaen los fundamentos persuasivos que respaldaban las acciones -emprendedoras y ofensivas- de cuantos, en estos escenarios, consideraban el juego político como algo cuya dignidad descalificaba el espectáculo de las confrontaciones obedientes a la ley de la esencial enemistad. La renuncia a los desvelos dialécticos-imprescindibles para que las ofertas gocen de empuje convincente- y el pedestrismo de lo rudimentario agotan la cantera de los argumentos que se manejan al respecto.

Tampoco se advierte el interés en descubrir nuevos yacimientos ideológicos y se prefiere apelar, sin exceso de mala conciencia, a referencias numerales o alegatos plebiscitarios de confianza social que defraudan cuando -con insinceridad pasmosa- atribuyen a quién sabe qué engaños el motivo de sus decepciones. Consumadas estas frustraciones, el falso empeño de especulación se desvanece y arroja por la borda los restos de flexibilidad que aparentaba para ilustrar las sombras de su imagen.

La decadencia de la creatividad ideológica es un mal que no se cura invocando ciegos deberes de adhesión, ni lanzando acusaciones de infidelidad que, alentadas por lo suyo de empavorecimiento, fulminan la disidencia de las conciencias rectas y avezadas a censurar el impune pecado venial ( $\dot{i}$ ) que constituye la calumnia en la vida pública. La implementación de las aventuras ideológicas incluye, como cláusula idónea para sortear los escollos del momento, una presunción de respeto -en pro de quienes dirigen esas operaciones- y un compromiso de paciente espera, a la vista de las ceremonias con que la confusión y la mentira solapan su descrédito. El perecimiento de las ideologías es -mucho más que la condena de la sociedad a perder la fe en la credibilidad de sus promesas- la confesión del desaliento que causan ciertas verdades animadoras de su puesta en escena, el desinterés en llegar al fondo de las cosas y la avidez por invadir -deprisa y sin escrúpulos- los es- 
pacios que, por derecho de conquista, quieren ocuparse. Una toma de posición señalada por lo vacuo de sus recursos doctrinales, orillando -con la complicidad de una opinión pública neutralizada o inmadura- las arduas tareas de la restauración de ese universo.

Ahí está la dificultad de definir lo que por justo ha de entenderse, si se quiere esbozar los perfiles de cada ideología y separar los campos en que se desenvuelve su acción competitiva. No es menos fatigoso el trabajo de reconstituir lo que - para advenir a una síntesis veraz y no viciada de falsificaciones- las nociones de igualdad y libertad van a encarnar. ¿Se mantiene el debate sobre el dilema que invita a elegir entre la protección de una libertad de los iguales -expansiva y generosamente administrada- y la preservación de una igualdad - urgida y controlada- de los ya liberados hasta un límite que no les es dado superar? La escisión sufre la cautividad intelectual de dos modelos. Uno, el de la tradición judeocristiana, fiel a la máxima de que nunca es libre la persona que no goza de oportunidades iguales para disfrutar de los bienes a que su condición de tal le da derecho. Adquirida la cual, cada individuo es titular de un derecho inviolable al pleno desarrollo de su cualidad de ser libre y a provocar las consecuencias legítimas que engendra el esfuerzo aplicado al consumo de esas libertades. Otro, el del maximalismo obtuso que -instigado por las reacciones de venganza y envidia- dice no a cualquier conato de liberación. Defiende que las libertades -lejos de propagar difusivamente el bien que las absorbe- tienden a un crecimiento controlable con la usura del reparto en que abunda la mezquindad igualitaria.

¿Cuánta es la dosis o cual la dimensión de la libertad compatible con una oferta ideológica madura y digna de consideración? Por evidente que sea la respuesta, no hay duda de que las luces proteicas de la libertad representan el objeto -imperfecto, evolutivo e insistente- de un ciclo natural de autorregulación que, algo así como marcando el paso, establece los ritmos de ascenso de la libertad y rinde cuentas del progreso que esta promoción ocasiona. Lo escenifican cuantos -como una muestra de feliz idea y no de apresurado arbitrismo- se comprometen a explotar el potencial de las expresiones y variantes que, según un método aceptable de determinación, acaparan el contenido esencial o núcleo invulnerable de la figura de libertad ejercitada. El axioma de que la libertad ocupa lugar, denuncia las limitaciones y la inestabilidad que acompañan a la historia de su descubrimiento y duración. Así se acusan el imperio de la solidaridad y el recato sociales, y se glosa la templanza de una libertad simultáneamente llamada al crecimiento. La cordura de esta proposición nada tiene que ver con los prejuicios y carencias de una libertad cercenada desde sus orígenes y en la que el reparto -más medroso que cauto- de sus objetivos impide educar a la persona humana en el mínimo de dignidad que le corresponde. La libertad -volviendo a lo dicho- ocupa lugar, porque sus impredecibles experiencias multiplican las zonas de habitabilidad y desarrollo, y porque sus versiones se enriquecen con ocurrencias nuevas que -a impulso de 
la verdad que las anima- van al encuentro de quienes las persiguen y de otras que - por afinidad, reflexión o contacto- se poseen en alguna medida.

Los esfuerzos de transformación-emprendidos por los poderes públicos en pro de la libertad efectiva que, si es plena, confirma el éxito de la revolución consumada en el seno de las instituciones y/o de la vida social de relación- no se encaminan a perpetuar una tutela reñida con la revigorización de las libertades personales. Existe un punto de inflexión, más allá de cuya divergencia los cambios desproporcionados pueden desestabilizar su espíritu y sus fines. El respeto que merece la libertad apoyada, se opone a las tentativas de sostenerla por tiempo indefinido, cuando -sin obtener una respuesta concluyente de la sociedad y de sus integrantes- decaen las energías que, a falta de estímulos, se desnaturalizan y desploman. Semejante punto de inflexión marca un momento de relevo que, si se elige con acierto, muda la situación y el compromiso de los individuos y los grupos sociales. Unos y otros soportan -como condición de un progreso resistente a dejar su espontaneidad bajo tutela- los gravámenes de sus libertades y la reordenación de los ingredientes -nuevos y antiguos, inéditos y clásicos- que de ellas forman parte.

Ante los apremios del tiempo político, de las urgencias comunicadas a la existencia individual por las perspectivas racionales y de las ensoñaciones de los seres humanos, no hay oferta ideológica que cuente con la serenidad y pausa suficientes para que sus destinatarios digieran las particularidades del programa que fije las etapas conducentes a esos resultados. Un programa que abarcaría el despliegue de los mecanismos del esfuerzo de liberación, la sistematización de las operaciones del cambio, la minuciosa comprobación de sus aciertos, la adopción inmediata de las rectificaciones pertinentes, la pedagogía del convencimiento de la cualidad de seres libres y la asunción de las responsabilidades que de todo ello se derivan.

Así se clama por una métodología de la educación que, como declara el art. 27.1 CE, equivale al desarrollo pleno -no mutilado, incompleto o escaso- que la persona adquiere cuando, sumida en su mundo circundante, arregla su comportamiento a los principios de la convivencia democrática -aptitud para coexistir en medio de la paz social, la predisposición cooperativa al servicio de los fines e intereses generales, y la distribución solidaria de los resultados habidos- $\mathrm{y}$ al deber de respetar el contenido esencial o núcleo invulnerable de los derechos constitucionales innatos. La severidad moral de esta propuesta denuncia la dispersión de los halagos y las medias verdades con que las ofertas ideológicas de hoy día se entregan a su propagación. Es indefendible -en pro del bien común que postula una libertad vivida con riesgo y sin miedo a la consecución de sus ventajas- la continuidad de ideologías, políticamente sucesivas, que, aunque se jactan de su fidelidad a los procesos de liberación, los interpretan con mucho más casuismo que el propio de una sana celeridad evolutiva. Sus acepciones y cambios de rumbo denotan una finitud distante de los valores a que se dicen vinculadas. Los hay 
que no transmiten a sus sucesores fórmulas valederas para inmunizar las líneas defensivas de los intereses que adoptan. Los hay que carecen de la lucidez y generosidad imprescindibles para asimilar el provecho de las aportaciones que les precedieron. La enemistad política fulmina los empeños en hallar soluciones que -acogidas a ensayos de coordinación o de alianza que limen su aspereza- no borran el antagonismo subyacente de sus protagonistas. Esta cruda verdad hace dudar de que, ante el enfrentamiento irreductible, los automatismos de la democracia salven del naufragio los elementos de conciliación y solidaridad que su maltrecha definición sigue exigiendo.

\section{POSIBILIDADES Y PERSPECTIVAS DIMANANTES DEL ACERCAMIENTO A LA IDEOLOGÍA DE LO JUSTO}

La ideología de lo justo publica el humanismo que, en clave social, orilla el pluralismo -inútil de presente- de las variantes cuya intervención no es un éxito o de las corrientes ideológicas afectadas por la imposibilidad de fraguar una síntesis tranquilizadora. Esta ideología o el óptimo accesible de sus operaciones han denunciado -amén de otros reparos- la parquedad de un pensamiento tan débil como sumiso a premisas de poca monta, que -para desoír la imputación de sus defectos incurables- se aleja de los focos de reflexión y de consejo. Los suplanta por los asentimientos de una audiencia artificiosa y escasa. Pasa por alto - más por desconocimiento técnico que por interés académico- la importancia de los retos de la economía. Elogia valores secundarios y propios de un discurso sin la convicción que facilitaría las adhesiones de cuantos -que son muchos- renuncian a su capacidad de comprensión y a la tarea de retornar a la normalidad. Exalta la creatividad inmerecida de actitudes personales marcadas por las ansias de megalomanía o-caiga quien caiga-por la codicia destructiva del bienestar de los demás. Propugna lecturas de la Historia que, cuando no niegan descaradamente la evidencia, se reinterpretan o reforman hasta el punto de presentar, como cambios de rumbo, situaciones apologéticas que ni de lejos producirán esos efectos. Pretenden convencer de que - pese a la levedad del repertorio moral e intelectual con que se actúa-la mentira es un obsequio inapreciable que mitiga la desesperación de quienes le otorgan su crédito. No obstante estas aseveraciones, aseguran que se cuenta con medios de transformación y de lucha merecedores de confianza.

La ideología de lo justo disuelve los reductos y purga las miserias del pensamiento único. Descansa en las reflexiones que defienden la necesidad de una opinión pública ilustrada y activa, la solución equitativa de los problemas económicos, en general, y, en especial de los nacidos de la mundialización, la efectividad del valor superior de la justicia como síntesis de la libertad e igualdad añoradas, la devolución no falsificada del poder político al pueblo mediante la concienciación y puesta al día de sus responsabilidades, el destierro de las conminaciones y requiebros con que los poderes democráticos halagan a una socie- 
dad cautiva de las orientaciones impuestas y, amén de otros secundarios, la conversión de la vida pública en el espacio de su plenitud y no en la diversidad de recovecos que -adictos a la feroz enemistad política- ensalzan la insinceridad y el hermetismo. Las anomalías imprevistas que la mundialización desencadena, conmueven las conciencias individuales y colectivas para que, a la luz de sus repercusiones en las vidas caóticas que dejan atrás toda esperanza, se agote el análisis de las transformaciones subyacentes a la magnitud de sus cambios.

La mundialización recogió el parecer de los reformadores europeos, que, según el yusnaturalismo idealista de la doctrina orden natural, anteponían la simulación de un inventario de necesidades a la verificación detallada de su historia, siendo así que los estados de conciencia de la época exigían sustitutivos fiables y abocaban a un yusnaturalismo realista pendiente de los episodios de entonces. Los llamamientos al espíritu público no congelaron la devoción por la modernidad codificadora que enfrentaba los fines de la universalidad -dirigidos a solidificar la ideología de lo justo y coasumidos por los países civilizados- con el discreto encanto de los nacionalismos emergentes. Si mundializar la convivencia en paz es prometer, sin dobleces ni exageradas apetencias, una existencia justa- no faltan parcelas del fenómeno cuya fertilidad depende del éxito de unos procesos que requieren la infatigable puesta al día de sus actividades de disuasión o de ofensiva.

Los efectos de la mundialización han resultado ser muchos y dispares. Comenzando por las menciones nominativas que enmascaran la gestualidad de su verdadero rostro -administración de las crisis de los procesos industriales- y estancándose en los umbrales de la tierra prometida de la Europa Social. Pese a las protestas testimoniales y las apariencias de progreso, perduran los recelos frente a la lentitud en perfeccionar una Política Social a la que los europracticantes se han adherido, desde sus principios, con alguna tibieza. No sienten la necesidad compulsiva de llevarla al grueso de un programa mundializador. Más bien, parece todo lo contrario. La tesis minimalista de la coordinación de las Políticas Sociales nacionales no las ha eximido del estigma de parientes pobres en la familia de las políticas comunitarias. El economicismo indisimulado de sus instituciones - potenciado por las inquietudes de la crisis- robustece su apuesta por los temas y soluciones de este signo y revela un propósito escuálido de dispensar a los derechos sociales la cobertura que les es debida.

La mundialización ha pervertido el Derecho Social a través de sus factores de degradación y su consabida lista de pretextos. A saber, el ejercicio irrestricto de unas libertades de establecimiento y circulación de capitales que olvidan sus funciones sociales, la desaparición o traslación a otros pagos de las bases físicas de la producción, la irrupción de tecnologías inaccesibes al conocimiento y a las reacciones de los sindicatos, el demérito de la negociación colectiva y el engrandecimiento de la contratación individual que engendra conflictos transversales o estratificados. Sin olvidar la complicidad de las instancias políticas -que contribuyen a erigir zonas de tributación de- 
bilitada - y la beligerancia con que los poderes económicos se ingieren en sus ensayos de voladura controlada.

El dominio, en este punto, de la ideología de lo justo -adepta a las directrices de una Moral participativa y ambiciosa- es de muy costosa introducción en un mecanismo político entregado -en régimen de dedicación exclusiva- a racionalizar técnicamente la vida económica y dar de lado a la severidad de las admoniciones moralizadoras. Invocación que es escasa o ausente en los propósitos manifestados al respecto. Las comunidades -más o menos ignoradas-afectadas por el espectro mundializador carecen de instrumentos útiles de promoción y propaganda para combatir, en condiciones de igualdad material, los excesos que las esclavizan.

No es fácil emitir, así las cosas, la predicción que asegure el retorno -siquiera templado y vigilante- al paraíso perdido de las adquisiciones sociales. Tampoco es improbable porque, amén de escribirse para el adoctrinamiento de la vida, la Historia atesora unas cajas de sorpresas que moderan los presagios más desoladores o determinan que, a la vuelta de la esquina de sus episodios, surjan los incentivos y experiencias que instalen a la persona individual en los espacios de una ciudad terrestre donde ame, sirva, conviva y edifique.

Ni es descabellado y ocioso que también un Derecho Social de corte universal - un Derecho de Gentes comprometido y arrogante- concite la intencionalidad y las acciones de cuantos -que son muchos- no desisten de forjar una humanidad más humana mediante la pedagogía del vivir justamente y la denuncia de los atentados que lo impiden. Acciones éstas, que, enmendando los excesos de la mundialización y reiterando la solidaridad cooperativa, repongan las existencias de una Política Social que, dañada por el desenfreno del neoliberalismo salvaje, se moviliza - pese a todo- en pro de su continuidad y salvamento.

\section{BIBLIOGRAFÍA}

BeLL, D. The end of ideology. Palo Alto (California): Ed. Free Press, A Corporation, 1963.

Bobbio, N. Politica e cultura. Milán: Ed. Einaudi, 1955; Destra e sinistra. Ragioni e significati di una distinzione politica. Roma: Ed. Donzelli, 1994.

CAHN, The sense of injustice. Nueva York: Ed. New York University Press, 1949.

FANON, F. Les damnés de la terre. París: Ed. Ediciones Maspero, 1961.

FERNÁNDEZ DE LA Mora G., El crepúsculo de las ideologías. Barcelona: Ed. Editorial Salvat, 1971.

GARCÍA DE ENTERRía, E. et al. «Le developpement de la politique sociale europeenne», Rapport du Comité des Sages. Bruselas-Luxemburgo: Ed. Comision Europea, 1996.

GramsCi, A. Para la reforma moral e intelectual, traducción de TORRell, J. Madrid: Ed. Editorial Santucci, 1982. 
Hernández Gil, A. Metodología del Derecho. Madrid: Ed. Antonio Hernandez Gil, 3. vols., 1971.

HerRero, J. Los orígenes del pensamiento reaccionario español. Madrid: Ed. Edicusa, 1971.

Julia, S. Elogio de Historia en tiempo de memoria. Madrid: Ed. Fundacion Alfonso Martín Escudero y Marcial Pons, 2012.

KunG, H. y Kuschel, K.J. Hacia una ética mundial, traducción de Grasset, L. Madrid: Madrid: Ed. Trotta, 1994.

LAMPRECHT. S.P. Naturalism and the Human Spirit. Nueva York: Ed. Krikorian, Y.H., 1944.

MANnHEIM, K. Ideología y utopia, traducción de Echavarría, S. Madrid: Ed. Fondo de cultura económica, 1997.

Marina, J.A. y DE LA VAlgoma, M. La lucha por la dignidad. Barcelona: Ed. Anagrama, 2000.

MarX, K. Die Frühhschriften von Karl Marx. Berlín: Ed. Landshut, S., 1953.

PetTA, P. Ideología constitucional de la izquierda italiana, traducción de Clavería, A. Roma: Ed. Savelli, 1978.

PoPPER, K. El mito del marco común, traducción de GALMARINI, M.A. Barcelona: Ed. Paidos, 1997.

Rossi, E. Il pensiero politico de Jacques Maritain. Milán: Ed. Edizioni di Comunita, 1956.

Santaella, M. Opinión pública e imagen política en Maquiavelo. Madrid: Ed. Alianza Editorial, 1990.

Santonastaso, G. Orientaciones actuales de las doctrinas politicas, traducción de JuberA, M. Buenos Aires: Ed. Editorial Troquel, 1991.

SELIGER, M. et al. «Ideology and politics», The new Enciclopaedia Britanica, vol. 20. Londres: Ed. Chicago University Press, 1989.

SEN, A. La idea de la justicia, traducción de VAlencia, H. Madrid: Ed. Taurus, 2.10. Touchard, J. Historia de las ideas políticas, traducción de PraderA, J. Madrid: Ed. Tecnos, 1970.

VACHET, A. La ideología liberal, traducción de FERnÁndez, V. Caracas-Madrid: Ed. Editorial Fundamentos, 1972.

VARGAS, R. El poder moral de la razón. Madrid: Ed. Taurus, 1985.

Zorrilla, M.M. «El Derecho Natural como técnica de racionalización», Sociología para la convivencia, pp. 153-178. Madrid: Ed. ZYX, 1966; «Modernidad y moralidad de la mundialización», Estudios de Deusto, vol. 50/2, pp. 181-196; «Eficacia y justicia del orden natural de la equidad», Estudios de Deusto, vol. 57/2, pp. 255-302; «Difusión extrajudicial del Derecho justo frente al reto del achicamiento del mundo», Estudios de Deusto, vol. 59/2, pp. 209-235.

TITLE: The spontaneity and simplicity of the ideology of the just.

RESUMEN: La plenitud del ordenamiento jurídico dota de un sistema de fuentes apto para facilitar una respuesta razonable y justa a las cuestiones de fondo suscitadas. Las ideologías que afluyen a esas aplicaciones tienen mucho que ver en ello. Son la causa y/o el efecto de los cambios 
inherentes al esfuerzo de transformación que sustituye la voluntad primitiva del legislador por la voluntad renovadora de la norma afectada por ese fenómeno. La sucesión de las ideología o sus derivaciones, muestra la grandeza y servidumbre de la influencia desencadenada sobre un ordenamiento jurídico exento de lagunas. Las rotaciones o interferencias producidas se registran un acceso instintivo a la ideología de lo justo, promueven las vías de su entendimiento saludable e introducen las ideas necesarias para culminar esta tarea laboriosa.

PALABRAS CLAVE: Plenitud, justa respuesta, esfuerzo de transformación, acceso instintivo, voluntad originaria, voluntad renovadora.

ABSTRACT: The plenitude of the juridical order provides a system of sources apt to give a reasonable and just reply to the questions of material law. The ideologies concerning to this situation play a relevant role. They are the cause and the effect of the changes inherent to the transformer effort, which replaces the primitive will of the legislator for the renovator will of the law affected by this phenomenon. The succession of the ideologies shows the grandeur and the servitude of the influence exerced on a juridical order free of hollows. The rotations and the interferences produced, determine an instinctive accession to the ideology of the just, promote the ways for a salutary understanding and contributes to perform this attractive task.

KEY WORDS: Plenitude, just replay, transformer effort, instinctive accession, primitive will, renovator will.

RECIBIDO: 13.09 .2013

ACEPTADO: 26.05.2014 